\title{
EPIDEMIOLOGICAL INVESTIGATION OF NOMA IN PAPUA PROVINCE IN 2017
}

\section{Penyelidikan Epidemiologi Noma di Provinsi Papua Tahun 2017}

\author{
Asrul Kaimudin ${ }^{1}$, Atik Choirul Hidajah ${ }^{2}$ \\ ${ }^{1}$ Field Epidemiology Master Program, Universitas Airlangga, asrul.kaimudin-2016@fkm.unair.ac.id \\ ${ }^{2}$ Department of Epidemiology, Faculty of Public Health, Universitas Airlangga, atik-c-h@ @km.unair.ac.id \\ Corresponding Author: Atik Choirul Hidajah, atik-c-h@fkm.unair.ac.id, Department of Epidemiology, Faculty \\ of Public Health, Universitas Airlangga, Ir. H. Soekarno Street, Mulyorejo, Surabaya, East Java, 60115, \\ Indonesia
}

\section{ARTICLE INFO}

Article History:

Received July, 27 $7^{\text {th }}, 2019$

Revised form January, $14^{\text {th }}, 2020$

Accepted January, $21^{\text {st }}, 2020$

Published online January, 28 ${ }^{\text {th }}, 2020$

\section{Keywords:}

epidemiology;

noma;

nutritional status;

dental and oral hygiene status;

korowai

\section{Kata Kunci:}

epidemiologi;

noma;

status gizi;

status kebersihan gigi dan mulut;

korowai

\begin{abstract}
Background: Indonesia Ministry of Health in October 2017 obtained information from the Public Health Emergency Operation Center (PHEOC) that there allegations of noma case in a toddler from the Korowai tribe in Asmat District. Purpose: This study aims to describe the magnitude of the noma problem, identify risk factors, and find other noma cases for prevention and control. Methods: This was a descriptive study using a case study approach. Primary data was obtained from interviews with family or close relatives of patients to obtain information about patient identity, medical history, and risk factors. Measurement of nutritional status and oral health was done by measuring weight or height and checking their oral health. Secondary data was obtained from Asmat District health office (Dinkeskab Asmat) and Yaniruma Health Center. The data analyzed were geographical, demographic, socio-cultural, transportation, and communication condition. Results: Noma sufferer was a 5-years-old child who lived in Afimabul village. There was not other cases of Noma found in Korowai tribal community. A long distance to reach health services and no availability of communication tools to Korowai tribe in Afimabul village made them inaccessible. The results of the identification of risk factors in 46 children found that the majority of them had low oral hygiene $(73.91 \%)$ and consumed uncooked water $(80.43 \%)$. Besides, some had an index of thin body weight (15.22\%), and very lean (6.52\%), and also found the suspected measles. Conclusion: There was only one case found in the Asmat district. Moreover, there were still found Korowai children with thin and very lean nutritional status and suspected measles who are risk factors for noma.
\end{abstract}

C2020 Jurnal Berkala Epidemiologi. Published by Universitas Airlangga.

This is an open access article under CC-BY-SA license (https://creativecommons.org/licenses/by-sa/4.0/)

How to Cite (APA): Kaimudin, A \& Hidajah, A. C. (2020). Epidemiological investigation of noma in Papua Province in 2017. Jurnal Berkala Epidemiologi, 8(1), 16-25. https:/dx.doi.org/10.20473/ jbe.v8i12020.16-25

\section{ABSTRAK}

Latar Belakang: Kementerian Kesehatan Republik Indonesia pada bulan Oktober 2017 memperoleh informasi dari Public Health Emergency Centre (PHEOC) bahwa terdapat dugaan kasus noma pada seorang balita yang berasal dari suku Korowai di Kabupaten 


\begin{abstract}
Asmat. Tujuan: Penelitian ini bertujuan untuk menggambarkan besaran masalah noma, mengidentifikasi faktor risiko, dan menemukan kasus noma lainnya untuk pencegahan dan pengendalian. Metode: Penelitian ini bersifat deskriptif dengan pendekatan studi kasus. Data primer diperoleh dari wawancara dengan keluarga atau kerabat dekat pasien untuk memperoleh informasi tentang identitas pasien, riwayat kesehatan, dan faktor risiko. Pengukuran status gizi dan kesehatan mulut dilakukan dengan mengukur berat per tinggi badan dan memeriksa kesehatan mulut. Data sekunder diperoleh dari dinas kesehatan Kabupaten Asmat (Dinkeskab Asmat) dan Puskesmas Yaniruma. Data yang dianalisis adalah kondisi geografis, demografis, sosial budaya, transportasi, dan komunikasi. Hasil: Penderita noma adalah anak yang berusia 5 tahun yang tinggal di Desa Afimabul. Tidak ada kasus noma lainnya yang ditemukan pada komunitas suku Korowai. Jarak yang jauh untuk menjangkau layanan kesehatan dan tidak adanya alat komunikasi untuk suku Korowai di Desa Afimabul membuat mereka tidak pernah mendapatkan informasi dan pelayanan kesehatan. Hasil identifikasi faktor risiko pada 46 anak ditemukan bahwa mayoritas anak memiliki kebersihan mulut yang rendah $(73,91 \%)$, konsumsi air tanpa dimasak (80,43\%), sebagian memiliki indeks berat badan kurus $(15,22 \%)$, dan sangat kurus $(6,52 \%)$, serta ditemukan seorang tersangka campak. Kesimpulan: Penemuan kasus noma hanya ada satu kasus di kabupaten Asmat dan masih ada anak-anak Korowai dengan status gizi kurus dan sangat kurus serta tersangka campak yang merupakan faktor risiko noma.
\end{abstract}

(C2020 Jurnal Berkala Epidemiologi. Penerbit Universitas Airlangga. Jurnal ini dapat diakses secara terbuka dan memiliki lisensi CC-BY-SA (https://creativecommons.org/licenses/by-sa/4.0/)

\section{INTRODUCTION}

Noma or cancrum oris, is a disease of necrosis that damages orofacial tissue (mouth), especially affecting children with poor oral hygiene and suffering from malnutrition. Noma disease is characterized by a rapid acute attack, usually starting from the mouth, spreading to the soft tissues and facial bones intraoral (Feller et al., 2014). The occurrence of noma starts from open sores in the mouth and swelling in the face that develops from gingival lesions, spreading to the bones under the face. Swelling of the facial area that becomes necrotic will destroy most of the soft and hard facial tissue, causing damage to the face and making facial skin hollow (Baratti-mayer et al., 2017). Swelling on the face appears after 24-48 hours, accompanied by inflammation of the gums (Whiteson et al., 2014).

Noma was first reported by Hippocrates in the $5^{\text {th }}$ century BC, and in the $19^{\text {th }}$ century, Richter reported noma occurring throughout Europe (Jain \& Ranka, 2017). In the late 1990s, acute noma occurred in countries bordering the Sahara and throughout the world, mainly in sub-Saharan Africa and Asia, with total cases between 100,000 to 140,000 per year. Ironically, the peak incident occurs in toddlers aged 1-4 years. Children who received medical treatment of these acute cases were found only about $15 \%$, while others were sent to live in exile rather than being taken to medical care, because noma was considered an embarrassing disease, thus often resulting in forced isolation from the community and family (Ashok, Tarakji, Darwish, Rodrigues, \& Altamimi, 2016; Braimah, et al., 2017). Noma generally occurs in populations with extreme levels of poverty, severe malnutrition, unsafe drinking water, poor sanitation, poor oral hygiene, high infant mortality, limited access to health services, and intrauterine growth retardation (Baratti-mayer et al., 2017).

Noma disease is rare in high-income countries and mostly occurs in Africa and developing countries, especially in children under the age of 6 years (Braimah, et al., 2017). Several studies have found that risk factors for noma are poverty, stunted growth due to malnutrition, measles, 
malaria, low food microbiology, and sociobiological (Srour, Marck, \& Baratti-mayer, 2017). Other research also found that noma cases occuring in Northern Nigeria were caused by a lack of maternal care. This is because mothers leave their babies after giving birth and cared for by their grandmothers. Grandmothers who lack knowledge about balanced food, cause malnutrition in infants which can have an impact on the emergence of noma disease (Ashok et al., 2016).

On October $3^{\text {rd }}, 2017$, the Director of Surveillance and Health Quarantine obtained information from the Indonesian Child Protection Committee (KPAI) that it was found a toddler came from the Korowai tribe of Papua who needed special attention and prompt treatment because of a serious health problem. The case was referred to Dian Harapan Jayapura Hospital, which is one of the hospitals that cooperates with the Papuan government using Healthy Papua Card (KPS) management (Ministry of Health RI, 2017).

The results of information verification carried out by the Public Health Emergency Operations Center (PHEOC) Directorate General of Disease Prevention and Control on the relevant unit, stated the case was allegedly "Noma". Noma is a rare disease in Indonesia, so it was decided to do an epidemiological investigation to find other noma cases so that treatment can be done immediately. The aim of the Noma epidemiological investigation in the province of Papua is to describe the magnitude of the noma problem (based on person, place, and time), identify risk factors, and find other noma cases.

\section{METHODS}

The research design used was descriptive using a case study approach. This research was conducted at the Korowai tribal community in Asmat District, Papua Province. The population of Noma investigations was all Korowai tribe people who were in the areas or villages that can be reached as many as 46 people. The investigation area was conducted in three out of 11 villages in the Asmat or Boven Digoel districts, namely the villages of Danowage, Afimabul, and Sinimburu. The target of the investigation was the sufferer and everyone who suffers from toothache, swelling, and mouth ulcers. The data collection instrument used referred to the guidelines for investigating and managing the outbreak of infectious diseases and food poisoning by the Ministry of Health of the Republic of Indonesia in 2011 which has been modified with a differential diagnosis of noma, namely leprosy, leishmaniasis, post-azar dermal leishmaniasis, oral cancer, clostridial or streptococcal gangrene, and stewart granuloma. There were no specific guidelines for the prevention and control of noma diseases in Indonesia, so modifications were made to the data collection instruments.

The data sources used were secondary data and primary data. Secondary data came from the Asmat District Health Office (Dinkeskab Asmat), Yaniruma Health Center, and Dian Harapan Jayapura Hospital, which was a hospital where noma patients were being treated. The data analyzed were geographical, demographic, sociocultural, transportation, and communication conditions. Primary data were obtained from interviews with family or close relatives of patients to obtain information about the patient's identity, medical history, and history of other diseases. The nutritional and oral health status in the Korowai tribal community was done by measuring body weight per body height and checking oral health directly. The data obtained were then analyzed based on an epidemiological approach (person, place, and time) and risk factors from Noma. Data collected on October $22-28^{\text {th }}$, 2017.

The variables used in this study were the $\mathrm{BB}$ (Body Weight) index per TB (Body Height), water cooking habits, dental and oral hygiene status, and immunization status. Indicators used in community nutrition services were the Body Weight (BB) index per Body Height (TB) grouped into four categories: very thin $(<-3 \mathrm{SD})$, thin $(-3 \mathrm{SD}$ to $<-$ 2SD), normal (-2SD to 2SD), and fat (>2 SD) (Kemenkes RI, 2011). Water cooking habits were divided into two categories, namely boiled water and not boiled water. The status of dental and oral hygiene was divided into two categories, namely the habit of brushing (ever and never brushing teeth) and the condition of dental health (ever and never having a toothache). Immunization status was divided into two categories, namely given and not given immunization. The immunizations given are DPT-Hib, Polio, Measles and Vitamin A.

\section{RESULTS}

The Korowai is a tribe inland in Papua and was only discovered about 30 years ago. The Korowai tribal population is around 3,000 people. The Korowai live and stay in houses built in trees. The house is referred to as the "Tall House". Some Korowai houses even reach 50 meters above the 
ground level. Korowai is a tribe that does not wear Koteka. Until 1970, the Korowai tribe never knew of anyone other than their own group. In ancient time, the majority of Korowai tribes lived nomadically or moved around and also lived in trees in their isolated territories. Since 1980, some Korowai tribes had moved to newly opened villages namely Yaniruma, Basman (KorowaiCitak area), Mu and on the banks of the Becking River (Kombai-Korowai area). In 1987, villages were opened in Manggel, in Yafufla (1988), Mabul on the banks of the Eilanden River (1989), and Khaiflambolup (1998). The level of absenteeism in villages was still high, because the distance was relatively long between the settlement and food resources (sago) (Figure 1).

Asmat District is a division of Merauke District consisting of 10 districts. There are Agats, Atsj, Akat, Fayit, Kasuari Beach, Sawa Erma, Suator, Kolf Brasa, Unir Sirau, and Suru-suru. The district capital is located in Agats with a population of 76,577 people, and an average population density of 2.58 people $/ \mathrm{km}^{2}$. Geographically, Asmat District is bordered by Yahukimo District and Jayawijaya District in the north, while in the south is Boven Digoel District and Mappi District, whereas in the west is bordered by Mimika District, and in the east is bordered by Mimika District and Arafuru Sea.

The Korowai is spread over five sub-districts which are Firiwage, Yaniruma, Amasu, Suator, Siradela and four regencies which are Boven Digoel, Mapi, Asmat, and Yahukimo. The map of the Korowai distribution was made by Mr. Trevor (missionary) after traveling for weeks. The location of the Korowai Batu tribe can only be reached by helicopter, which takes three hours from Merauke. The journey to the Korowai tribe in Afimabul village, Asmat District, takes about 1015 minutes if taken by helicopter from Korowai Batu Danowage airport. The Ministry of Health of Indonesia integrated team traveled the Danowage route to Sinimburu village along the river using a motorized canoe or "ketinting boat" (2-3 hours) and continued to walk through the forest and swamps to Afimabul village in 6-7 hours (Figure 1).

The environmental conditions of the Korowai tribal settlement in three villages (Danowage, Sinimburu, and Afimabul) are surrounded by dense forests, shrubs, swamps, and rivers. The majority of the population lives in houses on stilts made of wood. The house is located six meters above the ground level and only a few living in houses built in trees and 30-50 meters above the ground level. The inhabited house does not have a window and only a door, so the situation inside the house is quite dark because the sunlight entering the house is less. The floor of the house is never cleaned and is always entered by pets like dogs and pigs. These pets usually sleep together with their owners in one bed. Garbage storage facilities are not available both inside and outside the home. Waste products and household wastewater are disposed of around houses and in rivers close to where they live.

The source of drinking water consumed comes from river water and rainwater by utilizing used asphalt barrels as water reservoirs. Besides, there is only one water reservoir in Afimabul Village that is used together. Korowai people do not have a toilet. They defecate in the forests and rivers close to where they live. Bathing and cleaning food are also done in rivers near homes and in water reservoirs. They live by hunting in the forest and gardening. The fields which are the place for farming are always on the move. Plants that are planted in general are bananas and cassava. The eating habits of the Korowai people still depend on cultures, namely the head of the family (men) eats first with more portions, then the remaining food is consumed by his wife and children. Other eating habits are consuming carbohydrates such as rice, sago, and cassava in more portions other types of food.

\section{Description of the Noma Case in Afimabul Village, Asmat District}

The Noma case was reported to have occurred on October $3^{\text {rd }}, 2017$, based on the results of the surgeon's diagnosis from the Dian Harapan Hospital in Jayapura. The Noma case occurred in Afimabul village or Kapayap III in the work area of the Kolofbrasa Health Center in Asmat District with a population of 180 people (Figure 2).

Noma sufferer reported was a 5-year-old girl with the initials "PA" and was still being treated at Dian Harapan Hospital in Jayapura. The sufferer was brought by the evangelist or priest (Dakinus) with his parents from Afimabul Village to Sinimburu Village on foot, then continued to Danowage Village by boat called "ketinting" to the house of Mr. Trevor (missionary). After that, they went to Dian Harapan Jayapura Hospital using a helicopter (Helivida) chartered by Mr. Trevor and financed by his personal money. The patient's condition had improved well after receiving medical treatment and the wound on the left cheek had begun to close. The surgeon in the Dian 
Harapan Jayapura Hospital was the doctor who handled these patient.

The results of investigations and interviews with the village head and the community of Afimabul village, obtained information that there were no other cases of noma or people who suffered swelling and ulcers or open sores in the mouth. Generally, people suffer from skin ache (cascade), itching, and children who suffer from intestinal worms. The doctors who are members of the joint health team had given treatment to people who suffer from skin aches, itching, and children suffering from intestinal worms. The people who live in Afimabul village also had never received health services, because no Community Health Center staff from the Community Health Centers Kolofbrasa had come to Afimabul village to provide health services. The people of Afimabul village looked forward to having health workers living together with them. Noma sufferers or families of patients could not be interviewed, because sufferers were still being treated in Jayapura and also the access to transportation was difficult. Moreover, there was no communication network and the distance was very long to the place where noma sufferers were treated.

The joint health team formed three teams to carry out further epidemiological investigations of the alleged noma cases in Danowage village, Sinimburu, and the location where the case was found was Afimabul Village. Based on investigations conducted in the three villages, information was obtained that no people suffered from toothache, swelling, and ulcers in the mouth or people with symptoms that resembled noma. The joint health team also measured nutritional status, checked dental and oral hygiene, administered immunizations, administered vitamin $\mathrm{A}$, and treatment in that three villages. Treatment was given to people who suffer from skin aches, itching, and intestinal worms.

\section{Nutritional Status}

Nutritional status measurements were carried out on 46 Korowai tribesmen in the villages of Danowage, Afimabul, and Sinimburu. The results of the measurement of nutritional status in the three villages showed that Afimabul Village which was a residence of people with noma, had a body weight index per body height which was thin (71.43\%) compared to Danowage Village. Body weight index per body height found in Sinimburu Village was very thin (66.67\%) compared to Afimabul Village. The majority of Korowai tribe people had a body weight index per body height normal (69.57\%) (Table 1). Pregnant women with the status of Chronic Energy Deficiency (KEK) were also found (1 case) when measuring the weight index per height in Danowage village.

The food intake that is eaten daily by the Korowai tribe is bananas and sago which are the main staples, but the Korowai people have not yet carried out well-managed cultivation. Sources of animal protein are obtained from hunting animals in the forest (wild boar, deer, poultry, reptiles) and also sago caterpillars obtained from decomposed sago trunks. Only a few communities consume shrimp and fish. The source of drinking water comes from river water and rainwater by utilizing used asphalt vats as a water reservoir. There is only one water reservoir in Afimabul village built since 2016 and is used together.

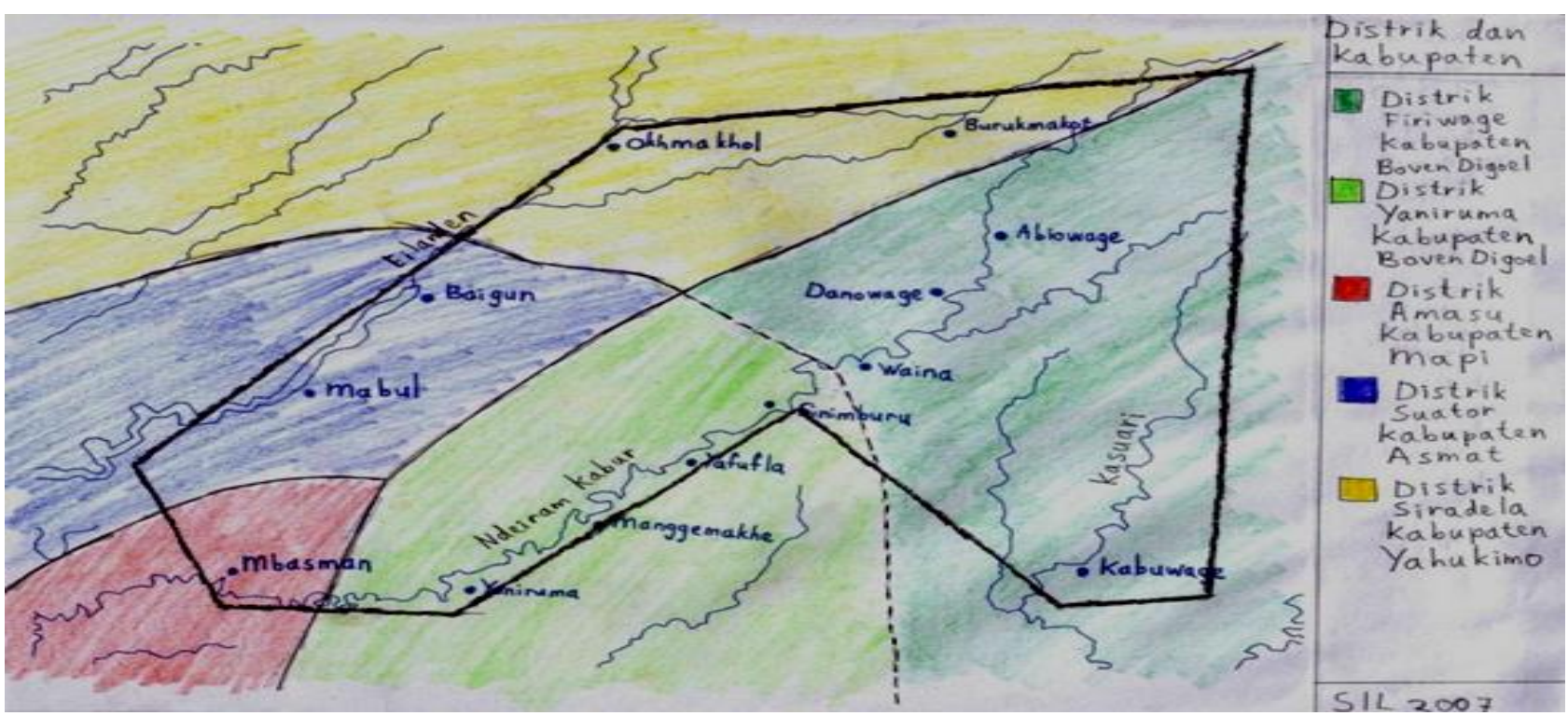

Figure 1. Korowai Tribal Location Map, Papua Province 


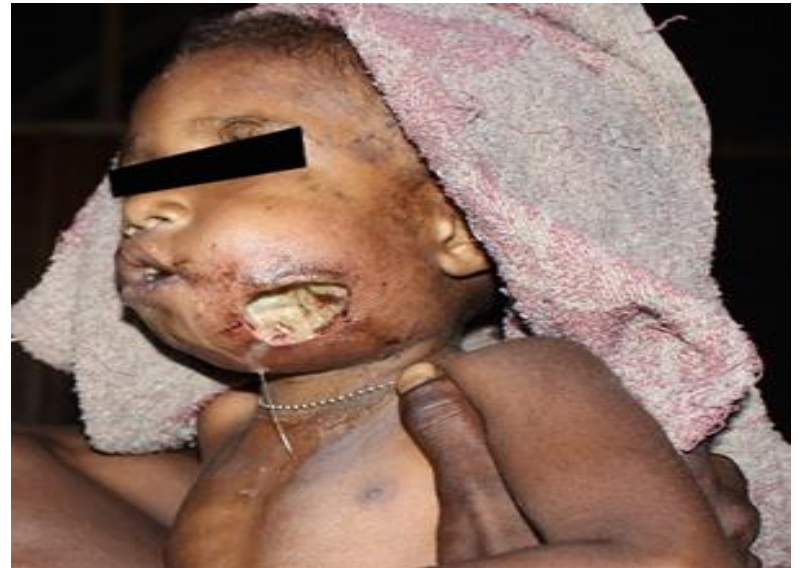

Figure 2. A noma patient from Afimabul village, Asmat District, Papua Province

The majority of Korowai tribe people drink rain water and river water without cooking at first $(80.43 \%)$. Afimabul Village is the village with the largest percentage that drinks rain water and river water without being cooked first $(37.84 \%)$, followed by Danowage Village $(32.43 \%)$, and Sinimburu Village $(29.73 \%)$ (Table 1). The Korowai people do not have family toilets, so defecation is carried out in the forests and rivers around settlements. Bathing and cleaning food is also carried out in rivers around settlements and in water reservoirs.

\section{Dental and Oral Hygiene Status}

Dental and oral hygiene checks were carried out in the villages of Danowage, Afimabul and Sinimburu amounted to 46 children. The results of this examination showed that most had never brushed their teeth $(73.91 \%)$ and only a small portion had experienced toothache $(10.86 \%)$. The majority of children do not know how to brush their teeth properly. Those who once brushed their teeth and knew how to brush their teeth properly because it had been taught by the Lentera Harapan school in Danowage Village. Children in Afimabul village, where noma cases were found, never brushed their teeth and did not know how to brush their teeth (Table 1).

\section{Immunization Status}

Provision of immunization and vitamin $\mathrm{A}$ in the villages of Danowage, Afimabul and Sinimburu amounted to 46 children. Measles was the most vaccine given at the time of treatment (Table 1), considering that there were suspected measles in toddlers with red eyes and red spots all over the body as well as body temperature or high fever. Based on the information obtained, Korowai people who were in Afimabul village or residence of noma sufferers had never received immunization services. Danowage and Sinimburu villages were villages that have received immunization services, but immunization services were rarely provided, because the transportation was difficult to access either from the village to the puskesmas or vice versa.

\section{DISCUSSION}

Noma is a necrotizing disease that can destroy the mouth and face. The causative agent of noma is still unknown whether it is caused by a viral or bacterial infection (WHO, 2016). Pathogens Fusobacterium necrophorum and Prevotella intermedia are the main pathogens that are suspected to cause noma (Neville, Damm, Allen, \& Chi, 2019).

Noma starts from lesions (sores) on the gums in the mouth. Symptoms of this disease begin in the lesions in the gums and then develop into ulcerative gingivitis, necrotizing which develops rapidly, destroys the soft tissues and bones of the mouth, and increasingly develops to perforate hard tissue and facial skin (WHO, 2016). Necrotic tissue usually appears blackish blue with a foul odor. Noma sufferers also often show pain, tooth loss, fever, tachycardia, increased respiratory rate, anemia, leukocytosis, and anorexia. Other main symptoms include scarring, trismus, speech and eating problems, facial defects, and psychological trauma (Neville, Damm, Allen, \& Chi, 2019).

The risk of noma disease mostly occurs in children aged between 2-6 years with a weak immune system, extreme poverty, poor oral hygiene, malnutrition, malaria, kwashiorkor (edema), measles, HIV/AIDS infection, and adult adolescents with weak immune system (Jain \& Ranka, 2017; Neville, Damm, Allen, \& Chi, 2019; Prado-calleros et al., 2017; Srour, Marck, \& Baratti-mayer, 2017; WHO, 2016). The results of research conducted on 159 cases of acute cancrum oris (noma) treated at Sokoto Hospital, Nigeria, showed that $42.20 \%$ of noma patients were accompanied by measles and $42.10 \%$ were accompanied by malnutrition. Patients who survived were $75.50 \%$ and died by $18.20 \%$. The 0 5 years age group is the most affected age by noma that is equal to $88.70 \%$ (Braimah et al., 2017; Ibikunle et al., 2017). Measles and malnutrition are the most common risk factors in noma patients (Adeniyi \& Awosan, 2019; Isezuo et al., 2018). Nutritional deficiencies occur when the body's metabolic needs do not match with the food intake and absorption. Some contributing factors are 
socio-economic conditions, medical history, and even psychiatric conditions (Stanislav, Tolkachjov, Alison, \& Bruce, 2017).

Malnutrition causes damage to lymphoid tissue in the T, thymus, spleen, Waldeyer ring, lymph nodes, and reduced lymphocyte counts, and $\mathrm{T}$ cells are positive for antibody-forming blood cells (CD4 and CD8), especially in children. The effectiveness of immunoglobulins becomes inadequate when antibody production requires the presence of $\mathrm{T}$ lymphocytes because the gingival inflammatory response in children is characterized by the presence of $\mathrm{T}$ lymphocytes, which can explain why periodontal tissue in malnourished children is more susceptible to periodontal disease or noma. The pain caused by chronic periodontal disease may be mild, but acute periodontal pain feels stinging, aching, and burning. The process of inflammation and infection in the bones can be characterized by continuous pain, swelling of the face, facial bone damage, and suppurating (Edens, Khaled, \& Napeñas, 2016; Whiteson et al., 2014). This study found that the majority of children living in Afimabul village or home of noma sufferers were included in the thin nutritional status category $(71.43 \%)$, and very thin $(33.33 \%)$, and found one pregnant woman with KEK (Chronic Energy Deficiency) status in Danowage village.

Factors such as malnutrition, weak immune function, and previous viral infections, are caused by poor oral hygiene (Hatcher \& Williamson, 2017; Lee et al., 2017; Maley, Desai, \& Parker, 2015). The results showed that the majority of Korowai tribe children never brush their teeth (73.91\%).

Table 1

Characteristics of Respondents in Korowai Tribe in 2017

\begin{tabular}{|c|c|c|c|c|c|c|c|c|}
\hline \multirow{3}{*}{ Variable } & \multicolumn{6}{|c|}{ The Village } & \multirow{2}{*}{\multicolumn{2}{|c|}{ Total }} \\
\hline & \multicolumn{2}{|c|}{ Danowage } & \multicolumn{2}{|c|}{ Afimabul } & \multicolumn{2}{|c|}{ Sinimburu } & & \\
\hline & $\mathrm{n}$ & $\%$ & $\mathrm{n}$ & $\%$ & $\mathrm{n}$ & $\%$ & $\mathrm{n}$ & $\%$ \\
\hline \multicolumn{9}{|l|}{ Weight/Height } \\
\hline Very thin & 0 & 0.00 & 1 & 33.33 & 2 & 66.67 & 3 & 6.52 \\
\hline Thin & 2 & 28.57 & 5 & 71.43 & 0 & 0.00 & 7 & 15.22 \\
\hline Normal & 13 & 40.63 & 10 & 31.25 & 9 & 28.12 & 32 & 69.57 \\
\hline Fat & 1 & 25.00 & 0 & 0.00 & 3 & 75.00 & 4 & 8.69 \\
\hline \multicolumn{9}{|l|}{ Water cooking habits } \\
\hline No & 12 & 32.43 & 14 & 37.84 & 11 & 29.73 & 37 & 80.43 \\
\hline Yes & 4 & 44.44 & 2 & 22.22 & 3 & 33.33 & 9 & 19.57 \\
\hline \multicolumn{9}{|l|}{ Dental and oral hygiene status } \\
\hline \multicolumn{9}{|l|}{ Habit of brushing } \\
\hline Never brushing teeth & 6 & 17.65 & 16 & 47.06 & 12 & 35.29 & 34 & 73.91 \\
\hline Ever brushing teeth & 10 & 83.33 & 0 & 0.00 & 2 & 16.67 & 12 & 26.09 \\
\hline \multicolumn{9}{|c|}{ The condition of dental health } \\
\hline Ever having a toothache & 1 & 20.00 & 3 & 60.00 & 1 & 20.00 & 5 & 10.86 \\
\hline Never having a toothache & 15 & 36.58 & 13 & 31.71 & 13 & 31.71 & 41 & 89.14 \\
\hline \multicolumn{9}{|l|}{ Immunization status } \\
\hline \multicolumn{9}{|l|}{ DPT-Hib } \\
\hline Not given & 7 & 29.17 & 8 & 33.33 & 9 & 37.50 & 24 & 52.17 \\
\hline Given & 9 & 40.91 & 8 & 36.36 & 5 & 22.73 & 22 & 47.83 \\
\hline \multicolumn{9}{|l|}{ Polio } \\
\hline Not given & 9 & 29.03 & 11 & 35.48 & 11 & 35.48 & 31 & 67.39 \\
\hline Given & 7 & 46.67 & 5 & 33.33 & 3 & 20.00 & 15 & 32.61 \\
\hline \multicolumn{9}{|l|}{ Measles } \\
\hline Not given & 2 & 20.00 & 3 & 30.00 & 5 & 50.00 & 10 & 21.74 \\
\hline Given & 14 & 38.89 & 13 & 36.11 & 9 & 25.00 & 36 & 78.26 \\
\hline \multicolumn{9}{|l|}{ Vitamin A } \\
\hline Not given & 4 & 26.67 & 5 & 33.33 & 6 & 40.00 & 15 & 32.61 \\
\hline Given & 12 & 38.71 & 11 & 35.48 & 8 & 25.81 & 31 & 67.39 \\
\hline Total & 16 & 34.80 & 16 & 34.80 & 14 & 30.40 & 46 & 100.00 \\
\hline
\end{tabular}


The majority of Korowai children who lived in Afimabul village never brush their teeth $(47.06 \%)$, and three of them have experienced toothache. Conditions like this can provide great opportunities for noma incidents. Poor oral hygiene can cause a reduction in host resistance and support the development of oral ulcers. This lesion can function as a place for the entry of microorganisms that are responsible for the disease process (Jain \& Ranka, 2017).

Noma is usually preceded by diseases that can decrease the immune system, such as measles, malaria, diarrhea, tuberculosis, or inflammation of the necrotizing ulcerative gums which are considered as risk factors or significant precursors to noma events (Jain \& Ranka, 2017; Srour, Marck, \& Baratti-mayer., 2017; WHO, 2016). Noma occurs mainly in poor communities who are untouched by health services and have a nomadic lifestyle. Noma cases are mostly reported in Africa and in the dry season when food is scarce and when the incidence of measles is high (Ashok et al., 2016). The Korowai are a tribe that lives in the inland of Papua. Papua is a tropical region. The Korowai live by hunting in the forests, nomadic, and are largely untouched by health services. This study found that Afimabul village never received immunization services, and found suspected measles in toddlers with red eyes and red spots all over the body as well as body temperature or high fever. Measles can be an important risk factor because it is associated with immunosuppression or inhibitors of antibody formation (Srour, Marck, \& Baratti-mayer, 2017).

Infections such as AIDS, measles, and malaria can cause changes from pro-inflammatory cytokines to anti-inflammatory cytokines (Ashok et al., 2016; Hatcher \& Williamson, 2017; Jain \& Ranka, 2017). Rapid hard and soft tissue damage seen in noma, can be associated with immunopathological responses to microbial factors and not just microbiological factors (Ashok et al., 2016; Khudhur, 2017; Whiteson et al., 2014). Bone changes in extra-articular ankylosis due to cancrum oris are affected by the destruction of the maxillary bone, malar bone, and in part of the mandible. The remaining bone is characterized by areas of sclerosis and distortion of the normal configuration with loss of trabecular patterns (Bagewadi, Awasthi, Mody, Suma, \& Garg, 2015).

Several studies have found that salivary urokinase, urokinase receptors, and vitamin D binding proteins are proteins that greatly influence periodontitis. These proteins are identified as candidates for salivary biomarkers for periodontal disease, which mostly begin as a host response to bacteria in dental plaque and accumulate on adjacent tooth surfaces (Herrera, Retamal, Bettina, \& Magda, 2018; Khudhur, 2017). Clinopathological conditions cancrum oris (noma) are also affected by trismus or disturbances in the jaw joints and facial muscles that control jaw movement and mastication (Bagewadi, Awasthi, Mody, Suma, \& Garg, 2015). Another study conducted on 120 HIV/AIDS patients also found that $82.50 \%$ had one intraoral lesion. Oral candidiasis, periodontitis, melanotic hyperpigmentation, gingivitis, and xerostomia are the most common oral lesions in HIV/AIDS patients. These lesions correlate with a decrease in the number of cell differentiation (CD4) (Frimpong, Amponsah, Abebrese, \& Kim, 2017)

Noma generally occurs in children under the age of six years, as well as in populations with extreme poverty, malnutrition, unsafe drinking water, poor sanitation, poor oral hygiene, high infant mortality, limited access to health services, living in remote areas that are difficult to reach, and delayed intrauterine growth (Jain \& Ranka, 2017; Srour, Marck, \& Baratti-mayer, 2017; Srour, Marck, \& Baratti-mayer, 2015). This study found that noma cases were five-year-old children living in remote and hard-to-reach areas. Most Korowai people still use rain water as drinking water and generally drink it directly without cooking it first. The Korowai tribe does not have a family toilet, defecation is conducted in forests and rivers around settlements, as well as bathing and cleaning food which are carried out in rivers around settlements and in water reservoirs. The staple food of the Korowai tribe is bananas and sago. Animal protein sources are obtained from hunting animals in the forest (wild boar, deer, poultry, reptiles) and sago caterpillars obtained from decomposed sago tree trunks, only a few people consumes shrimp and fish. The Korowai tribal community has difficulty to reach health services because of limited transportation and the distance between the residence and the health service which is very long. The majority of Korowai people prefer to use traditional medicine rather than health services.

\section{CONCLUSION}

Only one case of noma was found in Asmat District. It was still found Korowai tribe children with nutritional status of thin $(15.22 \%)$, very thin (6.52\%), never brushed their teeth $(73.91 \%)$. The majority of the population drank water without 
cooking (80.43\%), and one suspect of measles, and one pregnant woman with Chronic Energy Deficiency (KEK) which is a risk factor for noma disease. No other noma cases were found in the Korowai tribal community. The long distance to reach health services and no communication tools for the Korowai tribe in Afimabul village, made them never get information and health services. The Korowai people did not know their age, both adults and children, so the data cannot be analyzed by the age group.

\section{CONFLICT OF INTEREST}

The authors declare that no conflict of interest in this study.

\section{ACKNOWLEDGMENT}

We would like to thank the Asmat District Health Office, Yaniruma Health Center, and the Korowai tribal community in Asmat District, Papua Province, who collaborated and supported this research. We sincerely appreciate the participants, supervisors, and data collectors for their cooperation during the data collection.

\section{REFERENCE}

Adeniyi, S. A., \& Awosan, K. J. (2019). Pattern of noma (cancrum oris) and its risk factors in Northwestern Nigeria: a hospital-based retrospective study. Annals of African Medicine, $\quad 18(1), \quad$ 17-22. https://doi.org/10.4103/aam.aam

Ashok, N., Tarakji, B., Darwish, S., Rodrigues, J. C., \& Altamimi, M. A. (2016). A review on noma: a recent update. Global Journal of Health Science, 8(4), 53-59. https://doi.org/10.5539/gjhs.v8n4p53

Bagewadi, S. B., Awasthi, U. R., Mody, B. M., Suma, G. N., \& Garg, S. (2015). Bony fusion of the maxilla and mandible as a sequelae of noma : a rare case report. Imaging Science in Dentistry, 45(3), 193-198.

Baratti-mayer, D., Gayet-ageron, A., Cionca, N., Mossi, M. A., Pittet, D., \& Mombelli, A. (2017). Acute necrotising gingivitis in young children from villages with and without noma in Niger and its association with sociodemographic factors, nutritional status and oral hygiene practices: results of a population-based survey. BMJ Global Health, 2(3), 1-10. https://doi.org/10.1136/bmjgh-2016-000253
Braimah, R. O., Adeniyi, A. S., Olanrewaju, T. A., Ibikunle, A. A., Gbotolorun, M. O., Aregbesola, S. B., ... Bala, M. (2017). Risk factor and mortality rate of acute cancrum oris (noma in Sokoto North-West Nigeria: a 13-year survey. Journal of Pediatric Dentistry, 5(1), 1-5. https://doi.org/10.4103/jpd.jpd

Edens, M. H., Khaled, Y., \& Napeñas, J. J. (2016). Intraoral pain disorders. Oral and Maxillofacial Surgery Clinics of North America, 28(3), 275-288.

Feller, L., Altini, M., Chandran, R., Khammissa, R. A. G., Masipa, J. N., Mohamed, A., \& Lemmer, J. (2014). Noma (cancrum oris) in the South African context. Journal of Oral Pathology and Medicine, 43, 1-6.

Frimpong, P., Amponsah, E. K., Abebrese, J., \& Kim, S. M. (2017). Oral manifestations and their correlation to baseline CD4 count of HIV/AIDS patients in Ghana. Journal Korean Association of Oral and Maxillofac Surgeons, 4, 29-36. https://doi.org/10.5125/jkaoms.2017.43.1.29

Hatcher, J., \& Williamson, L. (2017). Noma in a patient with HIV. Lancet Infectious Disease, 17(6), 672. https://doi.org/10.1016/S14733099(17)30263-3.Noma

Herrera, D., Retamal, B., Bettina, V., \& Magda, A. (2018). Acute periodontal lesions (periodontal abscesses and necrotizing periodontal diseases) and endo-periodontal lesions. Journal of Clinical Periodontology, 45(20), 78-94. https://doi.org/10.1111/jcpe. 12941

Ibikunle, A. A., Adeniyi, S. A., Taiwo, A. O., Braimah, R. O., Gbotolorun, O. M., Soyele, O. O., ... Bashir, M. (2017). Management of 159 cases of acute cancrum oris: our experience at the noma children hospital, Sokoto. Medicine and Health Sciences, 5(2), 172-176. https://doi.org/10.4103/amhs.amhs

Isezuo, K. O., Sani, U. M., Waziri, U. M., Garba, B. I., Mohammed, Y., Legbo, J. F., ... Omar, M. (2018). Ecthyma gangrenosum on the face of a malnourished child with pseudomonas sepsis: simulating cancrum oris case presentation. African Journal of Laboratory Medicine, 7(1), 1-4.

Jain, A., \& Ranka, R. (2017). The real face of "face of poverty": an insight on noma. Hospice and Palliative Medicine International Journal, 1(2), 49-52. https://doi.org/10.15406/hpmij.2017.01.0001 1 
Khudhur, A. S. (2017). Identification and characterization of novel salivary biomarkers for oral inflammatory disease. Thesis. Dental Sciences, Newcastle University.

Lee, Y. J., Kim, Y. J., Won, C. H., Chang, S. E., Lee, M. W., \& Choi, J. H. (2017). Nomalike necrotizing stomatitis in a child with crohn's disease. Pediatric Dermatology, 34, 275276. https://doi.org/10.1111/pde.13212

Maley, A., Desai, M., \& Parker, S. (2015). Noma: a disease of poverty presenting at an urban hospital in the United States. JAAD Case Reports, 1(1), 18-20. https://doi.org/10.1016/j.jdcr.2014.10.001

Ministry of Health RI. (2011). Minister of health RI decree number 1995/Menkes/SK/XII/2010 concerning anthropometric standards for assessing children's nutritional status. Jakarta: Ministry of Health RI. https://doi.org/10.1055/s-0029-1219204

Ministry of Health RI. (2017) Coordination meeting on public health issues in Papua Province. Ministry of Health RI. Jakarta.

Neville, B. W., Damm, D. D., Allen, C. M., \& Chi, A. C. (2019). Color atlas of oral and maxillofacial diseases. Philadelphia: Elsevier Inc.

Prado-calleros, H. M., Castillo-ventura, B. B., Jiménez-escobar, I., Ramírez-Hinojosa, J. P., López-Gómez, A., García-de-la-Cruz, M., \& Dayan-Nurko, M. (2017). Noma and nomalike disease in HIV/AIDS patients, a comorbid interaction: a systematic review. The Journal of Infection in The Developing Countries, 12(2), 89-96. https://doi.org/10.3855/jidc.9716

Srour, M. L., Marck, K., \& Baratti-mayer, D. (2017). Noma: overview of a neglected disease and human rights violation. The American Journal of Tropical Medicine and Hygiene, $\quad$ 96(2), 268-274. https://doi.org/10.4269/ajtmh.16-0718

Srour, M. L., Marck, K. W., \& Baratti-mayer, D. (2015). Noma: neglected, forgotten, and a human rights issue. International Health, 7(3), 149-150. https://doi.org/10.1093/inthealth/ihv001

Stanislav, N., Tolkachjov, M. D., Alison, J., \& Bruce, M. D. (2017). Oral manifestations of nutritional disorders. Clinics in Dermatology, 35(5), 441-452. https://doi.org/10.1016/j.clindermatol.2017.0 6.009

Whiteson, K. L., Lazarevic, V., Tangomo-bento, M., Girard, M., Maughan, H., Pittet, D., ...
The GESNOMA study group. (2014). Noma affected children from Niger have distinct oral microbial communities based on highthroughput sequencing of $16 \mathrm{~S}$ rRNA gene fragments. PLoS Neglected Tropical Diseases, $\quad 8(12), \quad 1-13$. https://doi.org/10.1371/journal.pntd.0003240 WHO. (2016). Noma is a severe disease It is treatable if detected and managed early! Africa.World Health Organization. 